IRA-International Journal of Education \& Multidisciplinary Studies

ISSN 2455-2526; Vol.10, Issue 02 (February, 2018)

Pg. no. 10-17.

Institute of Research Advances

http://research-advances.org/index.php/IJEMS

\title{
Performance Tasks in Developing Creativity in Education
}

\author{
Dr. Kemal KOÇ ${ }^{1} \&$ Dr. Ayhan AKSOY ${ }^{2}$ \\ ${ }^{1,2}$ Faculty of Education, Başkent University, Turkey.
}

Type of Review: Peer Reviewed.

DOI: http://dx.doi.org/10.21013/jems.v10.n2.p1

\section{How to cite this paper:}

KOÇ, K., AKSOY, A. (2018). Performance Tasks in Developing Creativity in Education. IRA International Journal of Education and Multidisciplinary Studies (ISSN 2455-2526), 10(2), 10-17.doi: http://dx.doi.org/10.21013/jems.v10.n2.p1

(C) Institute of Research Advances.

\section{(cc) BY-NO}

This work is licensed under a Creative Commons Attribution-Non Commercial 4.0 International License subject to proper citation to the publication source of the work.

Disclaimer: The scholarly papers as reviewed and published by the Institute of Research Advances (IRA) are the views and opinions of their respective authors and are not the views or opinions of the IRA. The IRA disclaims of any harm or loss caused due to the published content to any party.

Institute of Research Advances is an institutional publisher member of Publishers Inter Linking Association Inc. (PILA-CrossRef), USA. The institute is an institutional signatory to the Budapest Open Access Initiative, Hungary advocating the open access of scientific and scholarly knowledge. The Institute is a registered content provider under Open Access Initiative Protocol for Metadata Harvesting (OAI-PMH).

The journal is indexed \& included in WorldCat Discovery Service (USA), CrossRef Metadata Search (USA), WorldCat (USA), OCLC (USA), Open J-Gate (India), EZB (Germany) Scilit (Switzerland), Airiti (China), Bielefeld Academic Search Engine (BASE) of Bielefeld University, Germany, PKP Index of Simon Fraser University, Canada. 


\begin{abstract}
The creativity is a process which can be enhanced by education. The creativity process may be evaluated in the most efficient way by following the student studies. The significant point is to look at the events, ideas, rules, behaviors and objects from different perspectives and to experience it in the life itself. The creativity is an important dimension of learning. The creative thinking is vital for acquiring the information and the environments convenient to enhancing the creativity help learners to hold positive attitudes towards learning. In this study, the creativity and creative thinking which are crucial nowadays and assumed to increase its importance in the future are examined in terms of the relationship between "alternative assessment methods" and "performance tasks" which have entered into our education system in recent years.
\end{abstract}

Key words: Creativity, Creative thinking, alternative assessment methods, performance tasks, convergent thinking, divergent thinking.

\title{
Introduction
}

Today, the creative thinking has become one of outstanding concepts of knowledge era. Now this concept which was started to be discussed by pedagogues academically in 1950s, has been one of indispensible of miscellaneous disciplines such as economy, politics, engineering and technological studies. However, thinking and creative thinking come to these days from a breakthrough development process such as history of humanity. But the estimations concerning that thousandfolds of knowledge produced by the humankind until today will have been produced in the immediate future, have also proved the greatness of significance attributed to "creative thinking', today.

Today, the creative thinking has been perceived as the driving force of new production type of knowledge era which produces new information and at which the information is used such as a strategic product. The creative thinking plays a significant role in the architecture of a fast change with new expansions such as virtual reality, virtual product, etc. by overcoming the classic reality concept. The virtual realities or virtual products implicated in the brains, institutional power, computers and flexible production lines of teams who work together are the products of "creative thinking". Everything from car making, libraries to education and training activities is operated with virtualization.

Moreover, the traditional approach of "'Great minds think alike" has been transforming into "'Great minds think different' in the new expansions of creative thinking which drives fast change. Our customized functional and knowledge-based unique ways of using the mind and paradigms shows us that the great minds think different. In other words, the information is the basic raw material of creative thinking; the design created by processing the information and foresight based products are the treasures of our mind which transform into a real capability and ability [1-2 and 3].

The creative thinking way is a characteristic that the people need most. The societies which are not creative face the risk of being defeated in every field of comity of nations. In the ever-changing world, the new needs in every field and problems encountered drive the human to creativity and product new solutions [4]. The creativity is considered as a power which has been assigned to a few lucky persons. However, the creativity is not privilege of a few distinguished persons but it is a very significant behavior that every person who needs it may refer [5].

The characteristic which makes the creative person different is not qualitative but only quantitative. The creativity potential which is available in every person may be put into practice and activated. What is need for this is the preparation of necessary environment and conditions [6].

The creativity is a characteristic which is available in every human in various fields and at various densities. Therefore, it may not be exactly said that some people are creative while some are not. Every person may display less or more creative behavior. These creative behavioral differences in people depend on the participation, cultural environment, education and training [7] and the density of creative thinking and behaviors vary by these factors.

The researches indicate that the creativity is a significant dimension of learning. The creative thinking has a vital importance for acquiring the information; this is because the environments convenient to development of creativity help the children to develop positive attitudes towards learning and they have the quality of effective stimuli which make learning entertainment [8].

From this point of view, the "Alternative Assessment Techniques" which has taken place in our 
education system in the recent years have become a very significant learning process which enhance the creativity in children. The "Performance Tasks"' which we often prefer among Alternative Assessment Techniques and which are now essential for assessment as required by regulation has a significant characteristic aiming developing the creativity in children in this regard. However, it shouldn't be forgotten that the first requirement of achieving this for our children for whom we aim developing their creativities with performance tasks is to increase the number of our teachers whose creativities have been developed as well. This is because the architects of these performance tasks to be written for our students for whom we aim developing their creativities will be our teachers whose creativities have been developed.

\section{Dimensions of Creative Thinking and Performance Tasks}

Today, the humankind has been so multidimensional, creative and critical than ever before in its history. The educational institutions shall both make contribution to this change and to bring up the individuals who will produce new information from current situations as required by this change and who may think creatively and critically [9]. However, as stated by Cobb [10], the educational models based on transmission will not be able to put forth the desired learning. The education system based on internalizing the existing and its reproduction was not able to yield the desired result in developing high level of thinking skills. It is clear that this traditional models lie behind the critics concerning that the schools are not able to bring up productive individuals.

Depending on our insights and experiences, we may say that at first sight the creative thinking is an action which has no luxury individually. Is the creative thinking a routine thinking action really? Or it has more parameters than assumed? How may the creative thinking skill in education and the ability of design foresight be developed? Before reviewing these subjects, it seems helpful to analyze the dimensions of creative thinking within a definable education environment or at problem space.

An education environment is an education-training institution holding a special education philosophy and education strategies. This institution is constituted from socio-technical systems. The general and special aims of system are tried to be achieved with the technical efforts of institution and sub-systems.

In this regard, reviewing the creating thinking with technical dimensions devoted to philosophy-strategy, socio-technical-operative and practice may enable us to comprehend the subject area not only with a wide point of view but also a system approach.

This dimension of knowledge era intrinsically reflects on the education and compels the traditional education philosophy and education strategy based on this philosophy to change.

The creative thinking is seeing the problems and gaps in the information, developing opinions and hypothesis, producing unique idea, comprehending the relationship between the ideas, acquiring new combinations by developing thinking parameters and in conclusion, It is an approach of design and foresight.

The design and foresight symbolizes a free view, eluding from patterns and a search from known to unknown beyond all kinds of conditioning. Hall and Wecker [11] states that learning various viewpoints devoted to a problem will pull the individual through stereotyped thinking.

Based on these opinions, the below-mentioned aspects are rendered necessary in the creative thinking and design-foresight oriented education philosophy:

- Learning thinking and learning and dominating these functions on design and foresight in a scientific systematic pattern,

- Ensuring the solid, customized and functional information structuring,

- Arranging the education environment and education system in the way that the formation and development of creative thinking and design foresight skill may be ensured,

- Developing individual thinking parameters.

It is a known fact that the teacher centered teaching strategies which are widely used up to today may not drive the creative thinking. Transformation of teaching strategies into active teaching methods and active learning may go beyond the models-bound mental walls which may allow a wide range of thinking expansion.

On the other side, high level learning may be achieved within the frame of below-mentioned requirements 
based on the researches made:

- Active participation of students to problem solving processes,

- The students (and all elements of system) shall be responsible for their own learning and they may control this,

- The administration, teachers and students may use their creativities, introspection and research skills,

- Integrating the concept, hypothesis and practices,

- Exchanging views with others,

- Using past experiences and transferring information,

- $\quad$ Providing efficient learning environment.

From this point of view, the "'Performance Tasks" make significant contribution to achieve desired targets in creative thinking and design-foresight oriented education philosophy and to achieve high level learning.

This is because the performance assessment and portfolio assessment which require configuring the information meaningfully instead of its repetition without understanding are accepted within the alternative assessment methods. Since these kinds of assessments motivates the student for learning and they are devoted to developing the superior level mental skills and creativity, they conform to learning theories and they make significant contributions in fulfilling social needs in terms of preparing the students for real life [12].

\section{Mental Hierarchy and Performance Tasks in Creative Thinking}

First, the concept of learning thinking shall be taken in hand for defining the creative thinking. This is because learning thinking constitutes the first step in thinking hierarchy; and the creative thinking is configured on this.

The first step of learning thinking starts along with abolishing the barriers in the thinking system. Some conceptual barriers encountered within the process of thinking constitute mental walls which hider the person from comprehending, identifying and analyzing a problem in properly. The perceptual barriers among these prevent the person either identifying the problem or clearly comprehending the information necessary for solving the problem. We may clarify this type of perceptual barriers by special cases such as isolating the problem, identification disability, tendency of reducing the problem field unduly and not getting the habits of looking the problem from different perspectives.

The cultural values, interest, attention, sensitivity and motives of individual are significant factors in identification of problem with selective perception. The conceptual pace of individual determining his/her reactions by means of classifying or combining the stimulants of objects and events; saving the stimulants and tending towards identification by transferring the concepts previously acquired determine the perception capacity. The individual may perceive and identify the problems based on new information forms and concepts to the extent that he/she has enhanced his/her perception capacity. Therefore, the clues driving the thinking may be captured and the primary action motivating the mental hierarchy may occur.

The emotional barriers which prevent the thinking restrict the freedom of researching and changing the opinions. The fear of doing wrong, putting in jeopardy and being unsuccessful; having low endurance to uncertainties; having a great desire for security; preferring judging rather than creating opinion; clumsiness in the opinion density; the will of succeeding soon and not distinguishing the reality from imagination are the main emotional barriers.

The expression barriers prevent expressing the opinion and communication: decrease the association, thinking and expression fluency. We consider the act of expression consisting of messages which carry meaning or concepts as a psychomotor behavior which is impossible to separate it from development of thinking. The approach of solving the problem by using an incorrect language; insufficiencies in expressing and saving the opinions; subjective and relative concepts based on wrong and missing information are the expression barriers in the thinking system.

In the thinking hierarchy, the creative thinking horizons will have been opened along with overcoming thinking barriers.

The creativity means accessing new compounds by producing new information from current information in terms of individual. The creativity indicates producing new information from current information in terms of 
organization. If the innovation and uniqueness, in other words the creativity of individual or organization is not resulted from his/her/its own life experiences and knowledge but resulted from the contributions that they have made to the knowledge of humankind, we may mention about the real creativity.

Besides that the creativity is considered as the problem solving skill in the literature, in fact the creativity requires enhancing the performance, recognizing the problem, thinking different and solution. Especially, recognizing the problem plays a very significant role in the creative process.

The creative thinking means that estimations and deductions will be new, unique, skillful, clever and rare for individual. The creative thinker is the person who researches new areas, makes new observations, make new forecasts and deductions.

The creativity inherits recognizing and identifying a problem, searching for and trying possible solution ways and reaching a specific solution.

In order that the creative thinking and behaviors may come true, the individuals shall abandon taking the problems in hand with convergent and traditional patterns. When an opinion comes in the mind of an individual initially, the convergent thinking tendency arouses. The individual thinks whether this opinion in conformity with his/her own experiences and previous opinions or not. It is seen that the traditional education which promotes the convergent thinking dominates in this tendency. The individual who has adopted this attitude is an individual whose uncertainty tolerance is lower and who believes that there is a better way or right answer.

In general, the individuals get the habit of convergent thinking by long years of teaching devoted to finding a single solution way or finding the right answer. However, the individual shall abandon his/her knowledge, experience and expertness for a while and think divergent in the creative thinking.

The convergent thinking is a way of thinking which leads to traditional conclusions depending on a single correct and which is deducted from current information. The students try to find the solutions which seem true and conform to the cultural norms. An individual who has only adopted convergent thinking is probably a person who has no a wide imagination and it may not be expected from this person to be creative.

The characteristic specific to divergent thinking is producing various responses based on current information. These responses lie behind being evaluated as new, specific or creative. While the one who thinks convergent only seeks for the clearly correct answer, the one who thinks divergent has the characteristics of fluency in responses, in other words the number of solutions produced as response to a problem, compatible flexibility, configuring the comments and approaches again and in a different way, flexibility (not being stationary in thinking), uniqueness (newness of opinions produced) and processing (enhancing the opinions and solutions and elaborating).

The difference between convergent and divergent thinking depends on the difference in cognitive skills. The divergent thinking requires the ability of giving different responses by using miscellaneous information as a spring board for reaching multiple choices. In the divergent thinking, the association and expression fluencies are dominant.

In the divergent thinking, the new solutions which are unique are searched while it is laid emphasis on a single correct answer persistently in the convergent thinking. In current education system, the course practices and exam systems mostly support the development of convergent thinking. But a balance may be established between these two ways of thinking by encouraging the students to seek new responses for problems, catch different potential solutions and evaluate the sufficiency of alternative solutions regardless of which type the problems they encounter.

However, if the teacher insists on a single correct answer in order to gain time on teaching period as is often the case; in conclusion, the student will adopt a way of learning which seeks for a single acceptable response. On the other hand, if the teacher encourages seeking different ways of solution, the student will have the tendency to learn the ways of divergent thinking which makes contribution to more creative problem solving.

In authoritative cases, the way of convergent thinking becomes dominant in the students at the end of a life which has been substantially directed in a specific direction. In such an environment, the students get the habit of stereotyped and stationary thinking having only one single response or a single conclusion over time and they use this for every circumstance. The way of divergent thinking becomes dominant in the students living a democratic 
and insightful teaching environment; they have tendency towards trying different ways of solution without feeling a necessity to obey an aim or a standard and prefer seeking for new solutions rather than old known solutions. This is a very precious value for enhancement of creativity.

In the creative thinking, there are various factors which play a role in the reasoning, problem solving and transfer. However, there is a very significant factor in creative thinking. This is the prerequisite for student to abandon the traditional ways that he/she always use when organizing the information and to reject the hypothesis transferred without changing the previously learned ones as typically. In this regard, the student has to solve the significant problems with known materials in his/her hand but in new and unique ways. He/she should enter into a unique activity which has not come in mind previously.

On the other side, the creativity contains the divergent thinking [13-14] and everything that we will enhance the divergent thinking will make significant contributions to enhancing the creativity in our students.

One of the methods that we may use for enhancing the divergent thinking in our students as stated above is the "Alternative Assessment Methods" which take place within the constructivist approach. The performance tasks which are one of alternative assessment methods are significant aspects that we will ensure divergent thinking in our students and we will enhance the creativity. Offering real life problems oriented tasks which support enhancing the divergent thinking skills offers rich a wide range of opportunities to students in terms of producing new and different things. Offering the tasks in relevant contexts enhances the ability of producing solutions devoted to only a specific task but also all problems. Instead of close ended problems, the open ended problems make contribution to enhance the divergent thinking skill. The points to be emphasized here is to assess the process with the questions/tasks where there may be a different response for each student instead of assessing the process by focusing on the questions/tasks which a single correct answer for students. This makes the learning enjoyable while making significant contributions to enhance the creativity in our students. The well-written performance tasks are very significant in this regard.

\section{Performance Tasks in Developing the Creative Thinking}

Any circumstance or activity which limits the student's freedom of expression, independency, curiosity, investigativeness and self-confidence prevents the development of creativity. It is a fact that that some teaching practices has potentially harmful effects on the creativity. In this regard, classical assessment and evaluation methods have significant adverse effects on the learning environment and student. According to basic approach on which the classical evaluation is based, it is believed that there is reliable information about the world. While the aim for educators is to collect and transmit this information, the students are liable for acquiring the same understanding with this transmitted. The assessment and evaluation is based on at which level this information transmitted has been acquired. Therefore, an exam based on aims is used for measuring the success of student [15-16]. Here, the result assessment approaches are mostly used and the questions asked detract the students from enhancing the divergent thinking in students. The tests which in generally consist of very well-structured questions cause inconveniences on the creative thinking and on the other side, they hinder the students from enhancing their divergent thinking skills.

The students have no enough time for reading, reviewing, reasoning, criticizing or thinking divergent; they pay attention to final grades unnecessarily or all their learning efforts are indexed to final grade; therefore, a superficial goal is not put forth for student; it has no any interest to encourage and enhance their creative behaviors. Moreover, this artificial goal does not constitute a criterion for efforts of student and the single problem for student is not "how to get high final grades".

The same effects come to existence at the end of exams. The students determine their goals in accordance with the type of exams applied. When the objective tests are used continuously, they lead to adopt a way of limited study which may become a pattern. The exam system which is completely prepared from course material and which have a single correct answer prevents the creative thinking by getting the convergent thinking into a settled thinking habit (or reinforcing this habit) as well as that it assess and evaluates a limited knowledge.

The adverse effects on creativity may be also created by the learning itself. If a teacher is very strict or very authoritative, he/she may not tolerate emergence of divergent thinking products a bit more. This kind of teachers mostly tend to encourage the single correct answer, valid and creditable thinking and way of convergent behavior but not moving away the popular answers from time to time, the richness in behaviors, thinking different, producing fluently and the flexibility necessary for enhancing the creativity. 
The creative thinking compels the student to continuously seek for answers of various questions such as what, why, how, how much, what is known about this, what can be said, if .... what will happen?. Then, it is required to continuously make deep researches on the answers of questions such as "what else, what can be other than?. The student shall try to achieve the goal from different ways and he/she shall be encouraged to do this. Therefore, the teacher shall ensure taking creative steps by directing the student to think instead of giving the correct answers.

The creativity of which main characteristic is resulted from producing unique products is a process which takes time. The production of unique and original products does not sometimes occur immediately but it is achieved by a very slow progress not an immediate one.

When all these are taken in consideration, the use of performance tasks both as a learning process and assesment method is considered necessary for enhancing the creativity due to very significant justifications such as they mostly offer student to study independently, they contain a situation which arouses curiosity of student, it is process generally based on research, they allow for looking an event or subject from different points of view and there is always student at the center of every activity conducted. Every issue which is stated above as a barrier to creativity may be eliminated by well-written performance tasks and when they are used along with the traditional methods in properly, more efficient results may be taken.

\section{Result and Suggestions}

What has been learned is assigned by the things conducted within the process of learning. The information learned outside a significant frame is kept as information deprived of life. However, they are kept as dynamic information to be used in solving the problems which may be encountered thereafter at any time when they have been learnt within the problem solving steps. The transfer of dynamic information in creating new information is intrinsically easier and more effective.

In the problem oriented learning based on case studies, joint projects and teamwork, the data transfer may be done preeminently by the activities such as interdisciplinary product-energy communication, creating intersection, using information and producing new information.

The creative thinking in the form of learning being unique may be learned when two basic requirement has been fulfilled. One of these requirements is that there shall a requirement to be satisfied or a challenge to be overcome. The second basic requirement is that there shall be an information and understanding concerning to main phenomenon and principles. Otherwise, the creative thinking never occurs. The motivation and information is indispensible prerequisites of creative thinking.

They shall arouse the curiosity of students to prompt the will of learning being unique. In other to achieve this, it is required that the student shall face a specific uncertainty. The teacher shall be able to create questions, problems and circumstances which have the quality of arousing the curiosities of students. One of the methods to achieve this is to assign well-prepared performance tasks to students and to use this both as a teaching method and assesment method. Here, the most significant characteristic is that the student within the learning process is supported. Since the entire process is evaluated and in conclusion, it is aimed to develop a skill of student, this method takes time and it is very important to get the support and direction of teacher. Thanks to the guidance of teacher, the loss of time and risks may be mitigated easily. Here, the teacher is such a polestar which indicates the right direction. In this approach, the best way to learn the basic structure of subject is that the students shall find and discover this structure on their own. Discovering enhances the creative thinking. In order that the students may discover the basic structures, their active participation into learning process shall be ensured. The motive which prompts the students is being curious and successful and studying together. The performance tasks arouse the curiosity of students due to their characteristics and offer the opportunity of searching for, investigating and discovering the unknown and they have the quality of a satisfactory award for each student in terms of feeling the success. Moreover, one of its superior characteristics is getting the habit of teamwork by means of allowing for studying together when necessary. Therefore, below-mentioned issues shall be put into practice by using the performance tasks in education:

- The first step of creative thinking depends on abolishing the current barriers in thinking system. The adverse effects of these barriers may be reduced by education.

- The second step in providing the conditions convenient to creative thinking is getting rid of convergent thinking habits.

- The creative thinking is possible with divergent thinking approach. 
- The divergent thinking depends on the quality and quantity of process of creating and enhancing concept.

- The creative thinking process needs reading, investigating, questioning and criticizing activities. The creative thinking is adversely affected because of time limitation and since all learning efforts are based on final grade.

- The traditional exam system leads to settlement of a limited way of student which decreases the creative thinking motivation and which may turn into a habit and it turns the convergent thinking into a settled thinking habit.

- A program model which has been created in accordance with courses and subjects has adverse effects in enhancing the creative characteristics of students. However, the motivation and solid information are indispensible requirements of creative thinking steps.

- In the education, there are techniques which prompt the creative thinking. However, the tendencies of teachers and students towards studying together and sharing the experiences are insufficient.

- The individual education does not take the requirements in consideration. Everybody tends towards learning at same level.

- The teacher oriented education approaches and techniques adversely affect the creative thinking.

In order to develop the aforementioned needed cases and eliminate the adverse cases, the approach of "Alternative Evaluation Methods" is a learning process and different assessment approach which has not been used in our education system until today. This approach was used in our education system for a very limited period but it was taken out the system again due to very wrong practices. In order that we may bring up individuals having creative thinking skill which takes place among the essentials for people of knowledge era, we have to use this method in our system again in properly.

However, there are significant hitches especially resulted from our teacher's lack of knowledge and they need critical trainings on this subject. The creativity which is the subject of this article and "Performance Tasks" that we believe that they will enhance this have significant in terms of determining what kind of persons our students will be in the future. However, it shouldn't be forgotten that this new method may be used with the traditional methods in a very consistent way and the word of alternative which is used here does not mean that it takes place the traditional methods. These two methods may be used as supporter of each other and the success if indispensible when the conditions are ensured properly.

\section{References}

[1] Dökmen. U., Spontanlık ve Yaratıcılık, 1. Sistem Mühendisliği ve Savunma Uygulamaları Sempozyumu Bildirileri-I, (October 12-13, 1995), Ankara: Military Academy.

[2] Ergeneli, A., Yenilikçi Örgütlerde Yaratıcı Düşünme Eğitiminin Etkisi, 1. Sistem Mühendisliği ve Savunma Uygulamaları Sempozyumu Bildirilen-I, (12-13 Ekim 1995), Ankara: Military Academy.

[3] Il, S., Aktif Öğrenme: Eğitimde Öğrenci Özerkliği. Yaratıcı Düşünme ve Yaşam Boyu Öğrenme Motivasyonu, 1. Sistem Mühendisliği ve Savunma Uygulamaları Sempozyumu Bildirileri-11, (12-13 Ekim 1995), Ankara: Military Academy.

[4] Yolcu, E., Eğitimde Yaratıcılık Sorunu ve Sanat Eğitimi, Ilköğretim ve Sorunları Sempozyumu, Abant Izzet Baysal University, May 2-3,1995, Bolu.

[5] Yavuz (Yavuzer), H., S., Yaratıcılık, $3^{\text {rd }}$ Edition, Boğaziçi University Publications, Istanbul, 1996.

[6] Velioğlu, S. Akıl Hastası ve Sanatçı, Istanbul, 1978.

[7] Kırışoğlu, O., Sanatta Eğitim (Görmek, Anlamak, Yaratmak), Eğitim Kitabevi, Ankara 1991.

[8] Davaslıgil, U., Yüksek Gizli Güce Sahip Lise Öğrencilerinin Yaratıcılıkları Üzerine Deneysel Bir Araştırma, M. U. Ataturk Faculty of Education Journal of Educational Sciences, Issue:6, Istanbul, 1994,

[9] Gürol, M., (1995). Bilgi Toplumunun Eğitim Sistemi ve Bu Sisteme Eğiticilerin Yetiştirilmesi. 1. Sistem Mühendisliği ve Savunma Uygulamaları Sempozyumu. (12-13 Ekim 1995), Ankara: Military Academy.

[10] Cobb, P. (1994). "Where is the Mind? Constructivism and Sociocultural Perspectives on Mathematical Development" Educational Researcher, 23, 13-20.

[11] Hall, D., \& Wecker, D. (1996). Jump Start Your Brain: A proven Method for Increasing Creativity up to $500 \%$. New York: Warner

[12] Dietel,R.J., Herman, J.L., and Knuth,R.A. ( 1991). "What Does Research Say About Assessment?". http://www.ncrel.org/sdrs/areas/rpl esvs/assess.htm

[13] Arık, I. A., (1987). Yaratıc1lık. Ankara: Ministry of Culture and Tourism, (790).

[14] Rıza, E. T. (1999). Yaratıcılığı Geliştirme Teknikleri. İzmir.

[15] Jonassen D. H., (1992). Evaluating Constructivistic Learning. In David H. Jonassen and Thomas M. Duffy, eds. Constructivism and the Technology of Instruction: A Conversation. (137-148). Hillsdale, NJ: Lawrence Erlbaum.

[16] Bednar, A. K., Cunningham, D., Duffy, T. M., Pery, J. D. (1992). Theory into Practice. In David H. Jonassen and Thomas M. Duffy, eds. Constructivism and the Technology of Instruction: A Conversation. (17-34). Hillsdale, NJ: Lawrence Erlbaum. 